\title{
RECENT WORK ON DOCK CONTROL USING HORMONE WEEDICIDES
}

\author{
$B y$ R. B. GORDON, Department of Agriculture, Te Awamutu
}

THE constantly improving fertility status of our soils brings in its wake a list of associated problems not the least of which are increases in weed population both in variety and density. Under these higher fertility soil conditions eradication of harmful weed species in both pastures and crops is difficult and complex. The weeds like the desirable plants be they pastures or crops have soil conditions and environment to their liking and as a consequence develop a strong and vigorous plant structure, not the least of which is a vigorous and tenacious root system. A weed with such characters and one which is very widespread throughout the Dominion, persisting under extremely variable climatic conditions and soil types, is the dock species: Curled dock (Rumex crispus), broadleafed dock ( $R$. obtusifolius), or fiddle-leaf dock ( $R$. pulcher).

Under the modern systems of farming today, where the aim is constantly to improve soil fertility so the maximum of production per acre can be achieved, the problem of dock infestation is increasing and has now become a pressing problem with farmers as to the best methods of control to follow.

In the Waikato dairy farmers in particular are continually experiencing more trouble with dock infestation of their better pastures, and this is more accentuated on better-managed dairy farms where intensive methods of pasture and stock management increase the fertility. Under these higher fertility conditions a strong and vigorous plant develops, both in vegetative leaf and size of the taproot system. This density of leaf growth is damaging to pastures and their production. The mass of dock leaves smothers the pasture, particularly the clover and ryegrass species, and later causes the pasture sward to become very open. There is also loss of grazing in a thickly infested pasture. There are other farming systems in the country where docks are equally a cause of loss of production or a nuisance weed, such as in crop and clover seed production and lucerne stands.

Because of the nature and structure of the dock plant with its large, strong taproot system chemical control using various types of hormone herbicidal sprays has had varying success.

The results achieved to date in trial work carried out over the last few years by various Instructors in Agriculture in the Extension Division of the Department of Agriculture will be given, with particular reference to trial work carried out in the Waikato in the Te Awamutu instructorate by myself.

\section{EXPERIMENTAL PROCEDURE}

Since the spring of 1952 there have been 24 trials laid down on dock control throughout various districts of New Zealand, and of these seven have been laid down in the Te Awamutu instructorate.

These seven trials have involved a total of 58 plots, all in duplicate. Some of the plots in different trials have been subdivided in half and given further retreatments in an effort to gain further knowledge on measures of control.

All of the trials except one in the Te Awamutu district were designed for treatments to be applied at differing times and also stages of growth of docks. The trials concerned the control of docks in dairy pastures. 
Elsewhere in the Dominion eight trials were on dock control in pastures, four on fallowed or cropping land, three on cowgrass seed pastures, and two on lucerne stands.

When referring to docks in this paper, I mean the broad-leafed variety ( $R$. obtusifolius), on which 92 per cent. of the trial work has been based, and when referring to any other species, I will be specific.

\section{WEEDICIDES USED}

A total of 10 different types of hormone herbicides were tested out in various trials by instructors, and the materials were as follows:-

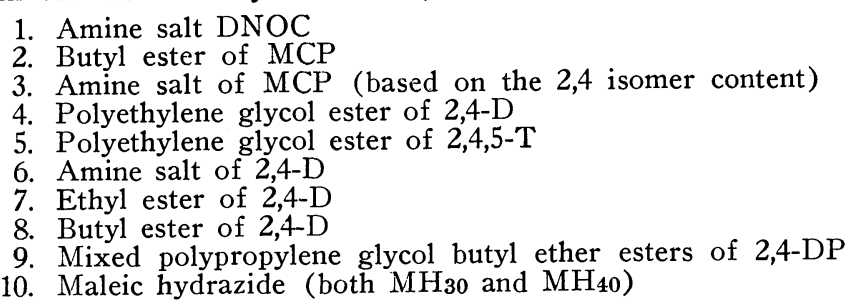

A fairly wide range of materials has now been tested for efficiency in controlling docks and because of this work the range of herbicides giving promising degrees of control has been considerably narrowed down, and certain conclusions can be drawn which are a helpful guide to future trial work. The polyethylene glycol ester of $2,4-D$ has been giving the most promising control and, therefore, has been used as a basis of comparison with untried materials, and formed the standard in most experiments, to the extent of 88 per cent. of the 24 trials which this paper is covering. The $\mathrm{MH}$ materials have formed a new line of attack, and $\mathrm{MH}_{30}$ has been tried in 28 per cent. of trials, with $\mathrm{MH}_{40}$ just over half of this amount. The butyl MCP has been extensively tried and was included in 33 per cent. of trials, the amine 2,4-D was included in 21 per cent. of trials, the amine MCP 13 per cent., and ethyl 2,4-D in 8 per cent. The other materials were tested in only one or two experiments.

\section{CONCENTRATION}

On analysis of recent trials the following are the concentrations of each material used. Rates are given in $\mathrm{lb}$. acid equivalent per acre.

1. Amine salt of DNOC at 1.6 and $4.81 \mathrm{~b}$. phenol equivalent per acre.

2. Butyl ester of MCP at 1 and $2 \mathrm{lb}$.

3. Amine salt of $\mathrm{MCP}$ at $2 \mathrm{lb}$.

4. Polyethylene glycol ester of $2,4-\mathrm{D}$ at $1,1 \frac{1}{4}, 1 \frac{1}{2}, 2,3$, and $51 \mathrm{~b}$.

5. Polyethylene glycol ester of $2,4,5-\mathrm{T}$ at 1 and $1 / 4 / 4 \mathrm{lb}$.

6. Amine salt of $2,4-\mathrm{D}$ at $2 \mathrm{lb}$.

7. Ethyl ester of 2,4-D at 2 and 4lb.

8. Butyl ester of 2,4-D at 1 and 31 b.

9. Mixed polypropylene glycol butyl ether esters of 2,4-D at 2lb.

10. (a) Maleic hydrazide $\left(\mathrm{MH}_{30}\right)$ at $0.8,1.8,1.6,2.0,3.3$, and $4.01 \mathrm{~b}$. maleic hydrazide equivalent per acre

(b) Maleic hydrazide $\left(\mathrm{MH}_{40}\right)$ at $0.45,0.75,0.9,1.0,2.0$, and $4.01 \mathrm{~b}$. maleic hydrazide equivalent per acre.

The polyethylene glycol ester of 2,4-D and the $\mathrm{MH}$ materials have been used to a greater degree and at varying concentrations in an effort to determine at what strength the must efficient kill is obtained. From 
initial work the evidence pointed to the need of heavier concentrations of hormone herbicides, if some measure of control was to be achieved, and this is readily understood when the structure of the plant is considered, with its large stout taproot which can hold considerable reserves of plant food, and has remarkable powers of rejuvenation. Therefore, it has been found necessary to have a concentration of within the range of $2 \mathrm{lb}$. acid equivalent per acre in order to achieve some measure of control and yet be compatible with the minimum damaging effect on pasture or crop. In this respect some hormone herbicides have been more effective than others, and these have been the water based 2,4-D and the more selective MCP materials. The water based esters of 2,4-D have the ability of esters in penetration of leaf tissue, and the property of water based materials for translocation through the plants, features which are fundamental for efficient control of docks. Consequently the experimental approach to the problem has been to use the water based hormone herbicides at a concentration which should give a reasonable degree of control without undue harm to pasture or crop species. Some oil based esters of 2,4-D at equal concentrations have been tried and their effects noted in comparison with these other materials.

\section{SPRAY COVERAGE}

Adequate spray coverage of external plant tissue is very important for an efficient control and this can only be achieved if sufficient wetting agent is used. Water is the wetting agent and carrier for the hormone material in dock control and in most of the trials carried out rates of water have been 40 to 100 gallons per acre. However, 50 to 60 gallons water per acre should give adequate coverage of all dock growth, and it is the volume usually found the most satisfactory in trial work.

\section{STAGE OF GROWTH}

From early trial work it became apparent that the stage of growth of docks was an important factor in their control. In earlier experimental work established docks were largely treated when they were in vigorous leaf growth, coinciding with the early to mid-spring period being at a time and the docks at such a stage of growth which it was generally accepted as the best period for treating and controlling troublesome pasture weeds. However, it has since been found docks are a law unto themselves, and require treating at a time and at a stage of growth which is not usually compatible with the best degree of control for other pasture weeds.

Most trial work carried out outside the Waikato has been of single application only and applied in December-January on mature docks, when the treatments have been the polyethylene glycol ester of 2,4-D with other MCP and/or 2,4-D materials or, applied in September or autumn on leafy rosette stage plants, with polyethylene glycol ester of 2,4-D as a treatment in conjunction with $\mathrm{MH}$ materials and other hormone weedicides.

Trials in the $\mathrm{Te}$ Awamutu district were initially commenced in early spring and respraying on regrowths on a portion of the plots given at different intervals, in the early summer and early autumn. Later trials were planned whereby treatments were applied at monthly intervals of October, November, and December. This timing at different stages in the maturity of established dock plants was because of the indication from these earlier trials that time of application in relation to the stage of growth of dock plants was critically important for effective control. This was achieved by spraying during November and December, when the dock plants were in full flower and seed head. Regrowth occurring after this time of application was considerably less compared with earlier spring sprayings, when the docks were in the vigorous full leaf rosette stage. 
Further sprayings have been applied on resultant regrowths and this follow-up method is being continued.

A trial has been laid down in early winter this year to control seedling docks in a young pasture sown this autumn. The materials used have been the butyl ester of $\mathrm{MCP}, \mathrm{MH}_{30}$, and $\mathrm{MH}_{40}$, all at $11 \mathrm{~b}$. acid equivalent per acre. To date the trial has not shown very much promise.

\section{PRE-SPRAYING MANAGEMENT}

It has become evident during the course of trial work that the prespraying management of dock infested pastures is important for two prime reasons.

1. Grazing off a pasture before spraying will allow greater weed leaf surface area to be exposed to the spray and the plants will therefore receive a thorough wetting and a toxic dose of herbicide.

2. The grazing prior to spraying also effectively reduces the extent to which the clovers are checked because of the reduced number of clover leaves present in a sward after stock grazing. A lower total surface area of clover tissue exposed to toxic spray droplets considerably diminishes the check given to the clover plants.

\section{INFLUENCE OF WEATHER}

The success achieved from spraying when water based weedicides are used will depend largely on the period of time before rain falls after treatment. If rain falls too soon after spraying, control is materially affected because of surface wash off diluting the weedicide absorbed by the plant tissue. This factor was well illustrated on a trial in the Te Awamutu district and points to the difficulty which can be experienced in wet seasons in obtaining favourable conditions for spraying when using water based materials.

\section{RESULTS}

Results wili be summarised in a description of each material used in recent trials.

\section{AMINE SALT OF DNOC}

In 3 trials where this material was used there were no effects on either the docks or the pasture and it can be considered of no practical use for dock control.

\section{ETHYL ESTER OF $2,4-D$}

There was only scant evidence on the effects: of this material. Only 2 trials contained this herbicide; the results from one trial were inconclusive and from the other the evidence of the last report made this autumn after the trial had been in progress for a year indicates a severe re-infestation of dock plants in both the 1.31b. and 4lb. acid equivalent per acre treatments. The clovers were severely reduced and depressed initially, but the white clover has now recovered fully, though the red clover has been severely affected.

\section{BUTYL ESTER OF 2,4-D}

There was only one trial containing this material and it was the same one with the treatments of ethyl ester of 2,4-D as above. Concentrations of butyl ester 2,4-D were 1 and 3lb. acid equivalent per acre and on both there has been a severe re-infestation. Clover plants, though severely affected at first, have now after a year's time, recovered fully in the case of white clover but with the red clover still severely reduced. 
MIXED POLYPROPYLENE GLYCOL BUTYL ETHER ESTERS

$O F$ 2,4-DP

This material has been tried for the first time in an experiment laid down late last spring. To date there has resulted some 30 per cent. of regrowth docks, and the clovers have all been practically annihilated. In view of this drastic effect on the clover this material does not seem to offer any possibilities for further investigation.

\section{SALTS OF $M H$}

Where salts of $\mathrm{MH}$ have been applied on established docks there has been practically no effect at all. However, on young dock plants some measure of control has been achieved and this appears very effective at the heavier rates of $\mathrm{MH}_{40}$ at about $41 \mathrm{~b}$. $\mathrm{MH}$ equivalent per acre, though in one trial $\mathrm{MH}_{40}$ at two light dressings, 0.45 and $0.751 \mathrm{~b}$. MH equivalent per acre applied at an interval of a month, shows promising results for some degree of control.

In broad red clover seed crops broad-leaf docks are troublesome and three trials laid down in Marlborough have given interesting results. Where the trials have been laid down in autumn and spring practical eradication of docks has been effected, though with the autumn trial, numerous seedlings appeared in spring. Rates per acre were 1,2 , and 4lb. $\mathrm{MH}$ equivalent per acre and it appears the lighter dressings are just as efficient as the heavier ones.

A trial was laid down in winter using $\mathrm{MH}_{30}$ and $\mathrm{MH}_{40}$ materials at 1,2 , and $4 \mathrm{lb}$. MH equivalent per acre, but there has only been a 50 per cent. kill at the heavy rate, and the lighter dressings have given progressively poorer control. It appears this material must be applied during periods of plant growth activity to be fully effective.

On pastures and broad red clover stands there is a slight check to clover growth activity for a while, but recovery soon occurs. There was some retarding of grass growth on pastures. One trial using $\mathrm{MH}$ materials in the control of docks in a lucerne stand showed there was no ill effect of this material on lucerne plants.

\section{BUTYL ESTER OF MCP}

Three trials with this material applied to established docks at the rate of 1lb. acid equivalent per acre when they were at the leafy rosette stage proved rather ineffectual. With a trial conducted in the Dunedin district, where plants were tabulated and critically watched and the roots examined on two separate occasions, the results indicated that too early conclusions on the success of control achieved should not be drawn. Examination of rootstocks 3 months after spraying appeared to indicate very good control. However, on further examination 9 months later a more accurate picture revealed only some 50 per cent. of a kill. This was on broad-leaf dock at the flower-head stage, using 21b. acid equivalent per acre. At the leafy rosette stage of growth control was even poorer. On a trial in the Te Awamutu district with broad-leaf dock, where monthly applications were given during October, November, and December at the rate of $2 \mathrm{lb}$. acid equivalent per acre, a very poor control was achieved with the October spraying, but quite a good one obtained during the other months when the plants were in the flower seed head to the extent of 75 per cent. reduction. However, with a similar type of trial on fiddle-leaf dock the control achieved was similar, but practically effective on each of the 3 monthly applications. December spraying definitely gave a better control with less regrowth.

Summarising the effectiveness of butyl ester of MCP it can give reasonably good control, provided it is applied at the concentration of 2lb. acid equivalent per acre in December, when docks are fully mature. White clover received a temporary check, but recovered very well. 
AMINE SALT OF MCP

This material has oniy had a limited trial on dock control and was included in two experiments laid down last spring at $21 \mathrm{~b}$. acid equivalent per acre.

On young established docks treated in September a very poor control has been achieved, and in a trial with treatments in November-December there appears to be about 60 per cent. control. Clover reduction has only been moderate.

\section{AMINE 2,4-D}

Like the butyl ester and amine salt of MCP the amine salt of 2,4-D has given rather poor control on established leafy rosette plants, though better control is given on the mature docks in flower and seed head.

All trials were at $2 \mathrm{lb}$. acid equivalent per acre.

After a year on a trial with broad-leaf dock applications given in November resulted in an 80 per cent. control; in a December treatment an estimated 90 per cent. control was effected.

A similar trial laid down a year later is showing a similar pattern of control as did the earlier one.

With fiddle-leaf dock a 70 per cent. kill was achieved with OctoberNovember spraying, but an 80 per cent. kill was obtained from a December treatment. With this material clovers are given a check, but recovery is quite good.

\section{POLYETHYLENE GLYCOL ESTER OF 2,4-D}

It is with this material that much of the recent experimental work has been based and used as a standard when comparing the efficiency of other untried chemicals. In 24 trials covered by this paper polyethylene glycol ester of 2,4-D has been used in different concentrations and as a standard in 21 of them. It has been tested under varying conditions a standard in 21 ar of $N$. Zealand and valuable information has and in from these trials that yielded from the numerous triat 2lb. acid equivalent per acre give a relatively poor degree of control on established docks at most stages relatively poor dere was nothing to be gained at higher rates. The trials which have given the most consistent effective control have been trials which have using this material at 2lb. acid equivalent per acre during NovemberDecember, when the established dock plants are in full flower and seed head.

Spraying at these times has given an 80 per cent. kill in November and about a 90 per cent. kill with a December spray, and to date a second trial a year later is showing similar trends in the control of broad-leaf dock.

With fiddle-leaf dock a November spraying has given a 70 per cent. kill and with a December treatment the efficiency of control has increased up to 80 per cent.

The white clover is given a temporary check, but recovers relatively quickly with little detrimental effect. However, red clover can be more severely affected, especially with spring applications.

\section{EFFECTS ON ASSOCIATED PASTURE SPECIES}

Grasses are little affected by the hormone sprays, though they may appear slightly damaged shortly after spraying, but they soon recover and are quite healthy, vigorous grasses, even to the extent of appearing and are quite healthy, vigorous grasses, some months have elapsed, and 21 
usually during a later period of pasture growth. This effect has been noticed to occur more with the oil based ester of 2,4-D.

$\mathrm{MH}$ materials are inclined to retard grass growth for a short time after application.

White clover is reasonably tolerant to most of the hormone sprays at rates commonly used, but is rather severely checked with the oil based esters of 2,4-D.

With the water based esters of 2,4-D and the esters and salts of MCP white clover is slight to moderately checked, depending on the material. However, where a moderately severe check occurs this is only temporary and in a few months the clover content again approaches normal. If dry tơ drought conditions follow spraying, full clover recovery is delayed and pasture growth can be affected. Red clover is much more susceptible to hormone sprays, in particular the oil based esters of 2,4-D. Trials on broad red clover seed crops using water based materials of $\mathrm{MCP}$ and $2,4-\mathrm{D}$ seem to indicate that where treatments were applied in late autumn there was little detrimental effect on the red clover, but spraying in spring during growth activity had rather a severe effect and considerably thinned out the clover crop. Stunting of red clover plants was rather severe when $\mathrm{MH}$ materials were used at heavy rates and gave diminishing effects with decreasing quantities.

On trials for eradication of docks in lucerne stands the hormone herbicides were toxic on the lucerne plants, except the $\mathrm{MH}$ materials, which did not seem to possess any detrimental influence.

In conclusion it appears the most effective method of control to date of established dock speciès in pastures is to spray during NovemberDecember, when the plants are in full flower and seed head; using either the polyethylene glycal ester of $2,4-\mathrm{D}$; : or the amine salts of $2,4-\mathrm{D}$ at a concentration of $21 \mathrm{by}$ : acid equivalent per acre, and on regrowths a follow up spraying to be applied the following autumn, when they are in full growth

Further respraying "can be given on remaining regrowths at the appropriate time unitil eradication is complete.

On young dock, plants effective control can be obtained by using $\mathrm{MH}$ at a concentration of 1 to $2 \mathrm{lb}$. $\mathrm{MH}$ equivalent per acre.

\section{DISCUSSION}

Q.-Did the speaker note any intense red coloration of dock leaves following applications. of $\mathrm{MH}$ to docks?

A.-Slight reddish coloration was noted. This was also noted by other instructors in reports: $\ldots$ i

Q.-Were MCP formulations used based on 2,4 isomer content or total acids of MCP:

A.-Butyl ester, the potassium and amine salts, were based only on the 2,4 isomer.

Q.-Some clarification of so called "water based" and "oil based" formulations is required.

A.- These terms are synonymous with water soluble and oil soluble.

Q.-Can the seeds of docks be controlled in the soil?

A.-Yes, TCA at rates over 201b and CIPC at rates over 41b, are successful as pre-emergence treatments in crops. 